w Poznaniu

agaczyz@amu.edu.pl

\title{
W poszukiwaniu języka skrzywdzonych. Wokól Ciemno, prawie noc Joanny Bator
}

\begin{abstract}
Aвstract: Czyżak Agnieszka. W poszukiwaniu języka skrzywdzonych. Wokót Ciemno, prawie noc Joanny Bator (Searching the Language of Hurted Creatures. About Joanna Bator's Novel Darkness, Almost Night). "Poznańskie Studia Slawistyczne" 9. Poznań 2015. Publishing House of the Poznań Society for the Advancement of the Arts and Sciences, pp. 209-222. ISSN 2084-3011.

The aim of the article is to present an interpretation of one of literary visions of traumatic experiences. Suffering a wrongs in childhood is, by the author, the main cause of many problems in grown people's life. Those wounds, psychical and physical, may not be cured. The destruction of emotional sphere of human personality causes also a damage of the language capable to express not only trials or harms but even commonplace experiences. Joanna Bator in her novel examines also the abilities of cultural patterns especially those permitting to understand the trauma dimensions and describes the changes of principles ruling a common life.
\end{abstract}

Keywords: child; emotions; trauma; language; experience; expression

Doświadczenia dzieciństwa mają wielki wpływ na dorosłe życie człowieka. Z jednej strony, literackie obrazy szczęśliwych lat dziecięcych, jakoby pozbawionych trosk dojrzałości i smutków starości, stały się rozpoznawalną konwencją, często wykorzystywaną w tworzeniu prywatnych mitów. Z drugiej strony, przeciwne wizje dzieciństwa nieszczęśliwego, sierocego, wypełnionego krzywdą i bólem odrzucenia również przekształciły się w oswojony, skonwencjonalizowany zapis doświadczenia przyjmowanego jako częste i nieusuwalne ze społecznego życia. W sferze poddanej tabuizacji najdłużej pozostawały traumatyczne relacje między dziećmi a ich rodzicami, zwłaszcza między dzieckiem a matką, choć i w tym zakresie ostatnie dekady przyniosły wyraźną zmianę, prowadzącą ku coraz częstszemu kwestionowaniu kulturowych ograniczeń. Jednak próby przekraczającego społeczne, obyczajowe (i literackie) konwencje mierzenia 
się z tematami o szczególnie trudnym charakterze zwykle prowadzą do poszukiwania języka zdolnego przybliżyć wymiar pojedynczego, osobnego przeżycia, jednostkowej, bolesnej traumy.

Doświadczenie egzystencjalne, zazwyczaj charakteryzujące się złożoną strukturą, konstytuuje się w ramach kulturowych wzorców. Jednostka, próbując nazwać (a zatem zrozumieć) doświadczenie, poszukuje gotowych reguł, odpowiedniego języka, obrazów, wzorców narracji, tym samym kształtuje je w toku dopasowywania do istniejących formuł. Teresa Walas stwierdza, że takie przeżycie - postrzegane przez jednostkę właśnie jako doświadczenie - pozwala włączyć się „miękko” w pole jednostkowej egzystencji, jeśli je rozpoznaje i sankcjonuje kultura (Walas 2012: 280). Włączenie może wszelako okazać się fortunne lub niefortunne - badaczka wskazuje na trzy główne przyczyny niefortunności. Pierwszą z nich należy uznać za szczególnie istotną ze względu na jej dwoisty charakter. Jest nią:

nowość, jaskrawa osobliwość, by tak rzec ,idiosynkratyczność” doświadczenia, które napotyka na nieczytelność w kulturze i nie znajduje dla siebie w jej obrębie form wyrazu i sposobów przyswojenia, jest jednak na tyle mocne, że opór ten odebrany zostaje jako defekt lub bezsilność kultury. Doświadczenie to może wówczas albo ulec „zapomnieniu”, swoistej eksterioryzacji, przekształcając się w rodzaj traumy, albo spowodować sproblematyzowanie języka i form kultury, a w konsekwencji niekiedy także ich zdynamizowanie czy transformację (Walas 2012: 281).

Krzywda wyrządzona dziecku - także w swych najbardziej drastycznych przejawach i niemożliwych do usunięcia skutkach - domaga się ekspresji. Bezbronność i zależność najmłodszych czynią z przeżywanej przez nich traumy tragedię o podwójnym wymiarze: jednostkowym (w ramach indywidualnej biografii, naznaczonej niemożliwymi do usunięcia czy wyleczenia ranami) oraz zbiorowym (dowodzi bowiem nieskuteczności wspólnotowych działań, które powinny służyć ochronie słabszych, niesamodzielnych istot). Narracje o dziecięcych ofiarach przemocy służą najczęściej tropieniu, nazywaniu i piętnowaniu wszelkich postaci zła, także w jego społecznym wymiarze.

Kulturowe obrazy dziecka i dzieciństwa ewoluują wraz z cywilizacyjnymi przemianami. Badania współczesnych socjologów wskazują, że proces ten uległ w ostatnich dekadach przyspieszeniu. Wielki wpływ na nieoczekiwane i trudne do zaakceptowania zmiany w wizerunku dziecka mają wszelkiego rodzaju media kultury masowej, dążące do eksponowania 
sensacji lub wręcz przekształcania w sensację przekazów dotyczących rodzinnych dramatów, społecznych zaniedbań, obyczajowych wynaturzeń. Małgorzata Szpakowska w Obyczajach polskich podkreślała ich negatywny udział w przemianie:

Dziecko, dawniej naturalnie budzące sympatię, dzisiaj często jawi się jako kat albo ofiara. Makabryczny kontekst nie może pozostawać bez wpływu na emocjonalną otoczkę towarzyszącą dzieciństwu. Ambiwalencję pogłębia umacniana przez media świadomość, że dziecko, nawet całkiem małe, może być obiektem seksualnym (Szpakowska 2008: 63).

W konsekwencji rodzi się i utrwala ambiwalentny lęk przed dziećmi (obok wzrastającej stale obawy o los własnego potomstwa), który zdaje się z jednej strony nieuchronnym kosztem uzyskanej przez dziecko autonomii, z drugiej zaś wyrasta z medialnego zgiełku towarzyszącego prezentowaniu kolejnych tragedii z udziałem dzieci. Badaczka dodaje:

Innym takim kosztem jest, jak się zdaje, pewna desentymentalizacja dzieciństwa. Można powiedzieć, że im słodszy jest dziś obraz dziecka, tym słabsze jego oddziaływanie. Dziecko-w-nędzy, figura popularna w pierwszej połowie wieku, było skuteczną konstrukcją do wywoływania wzruszeń; dziecko takie opisywano bądź w konwencji drastyczno-naturalistycznej, bądź w stylu, który do perfekcji doprowadził Kornel Makuszyński (Szpakowska 2008: 63) ${ }^{1}$.

Temat dziecka i jego egzystowania we współczesnym świecie nadal budzi emocje, zmienia się jednak język służący jego wyrażaniu. John Leavitt wskazywał na inny aspekt rodzących się trudności. Dowodził, że uznanie złożoności współczesnego modelu emocji prowadzi do koniecznego zaakceptowania ich funkcjonowania jako doświadczeń związanych nie tylko ze znaczeniem kulturowym, ale także z odczuciami cielesnymi. Badacz rozpatrywał skomplikowane relacje wyłaniające się w trakcie dookreślania kategorii emocji:

Podczas gdy są odczuwane i interpretowane subiektywnie, to zsocjalizowane istoty ludzkie - czyli myślące ciała ludzkie - odczuwają je w kontekstach społecznych. Oznacza to, że wytwarza, wyraża i odczuwa się je społecznie i symbolicznie. Wymagają

${ }^{1}$ Autorka kontynuuje rozważania: „Czułostkowość w postrzeganiu dzieci (i pisaniu dla dzieci) znacznie jednak osłabła w obliczu wojny, a po 1945 roku cios zadał jej realizm socjalistyczny". 
zatem przekładu (lub podlegają przekładowi) pomiędzy społeczeństwami i systemami symboli: nie tylko znaczeń, ale przynajmniej do pewnego stopnia ich odcieni uczuciowych (Leavitt 2012: 91).

We współczesnej kulturze zachodzi konieczność przekładania, wyjaśniania podlegających nieustannym przemianom emocji, zwłaszcza tych, które dotykają człowieka jako duchowo-cielesnej jedni, zanurzonej w zbiorowym bycie. Ryszard Nycz wskazuje na konsekwencje zapisywania, artykulacji doświadczenia w literaturze, przez co zyskuje ono charakter „całopsychocielesny” czyli hybrydyczny: „cielesno-zmysłowy, społeczno-kulturowy, pojęciowo-językowy, współtropiczny (jako rodzaj paradoksalnej wzajemnie związanej «pasywnej aktywności» doświadczającego i doświadczanego) oraz transformacyjny (wobec i rzeczy, i podmiotu)" (Nycz 2012: 45).

Podjęcie trudu tłumaczenia wymaga tropienia wszelkich niekonsekwencji i zafałszowań w analizowanym zjawisku. Joanna Bator w powieści Ciemno, prawie noc podjęła próbę wnikliwego rozpoznania przyczyn, a przede wszystkim skutków krzywd wyrządzanych dzieciom. Dołączyła tym samym do rosnącej liczby autorów dotykających tej problematyki², choć uczyniła to w odmienny sposób. Wpisując poważny temat w ramy sensacyjnej fabuły, autorka z jednej strony zabrała głos w społecznej dyskusji na temat przemocy i patologii w rodzinie, z drugiej - świadomie powiększyła grono swych czytelników o liczną grupę odbiorców łaknących nade wszystko sensacji, grozy, opowieści o zbrodni.

Wykreowana w utworze bohaterka, a zarazem narratorka utworu, zdaje się pozbawioną złudzeń reporterką od „spraw beznadziejnych”. Mówi z przekonaniem: „Zło nigdy mnie nie zaskakuje, ale zawsze dziwi. Nigdy nie przestanę się dziwić i dlatego umiem zadawać właściwe pytania” (Bator 2012: 53). Jednak jej wyprawa do rodzinnego miasta, odbyta w celu rozwikłania i opisania zagadki zaginionych dzieci, jest też powrotem do

${ }^{2}$ Wskazać można, poprzestając tylko na najbardziej interesujących czy najszerzej odbieranych przykładach: Białe klisze Zyty Rudzkiej (Katowice 1991), Absolutna amnezję Izabeli Filipiak (Warszawa 1995), Tabu Kingi Dunin (Warszawa 1998), Gnój Wojciecha Kuczoka (Warszawa 2003), Bidul Mariusza Maślanki (Warszawa 2004), Faustę Krystyny Kofty (Warszawa 2010) oraz Włoskie szpilki i Szum Magdaleny Tulli (Warszawa 2011 i Kraków 2014). Wspomnieć należy także o dramacie Marka Próchniewskiego Lucja i jej dzieci, wystawionego przez Teatr Telewizji w 2003 roku (później przekształcony także w słuchowisko radiowe). 
własnego, trudnego dzieciństwa. Beznamiętnej z pozoru narracji, odsłaniającej wszelkie, jakoby oczywiste dla dziennikarki śledczej, przejawy zła we współczesnym świecie, towarzyszą emocjonalnie nacechowane wspomnienia wczesnych lat życia, spędzonych z ukochaną, przedwcześnie utraconą siostrą. Wraz z nią pojawia się dziwna opowieść o „kotojadach”:

„Kotojady” mówiła Ewa „są wszędzie, za każdym razem przybierają inną postać (...). Są wytrzymalsze od wielbłąda, silniejsze od nosorożca. Żarłoczniejsze niż rekin ludojad. Trwają i żrą. Przenikają przez ściany, przez ciała, a gdy dostaną się do środka, sprawiają, że wszystko gnije i wypełnia się cuchnącą mgłą, jakby zepsuła się cała tona rokpola. Czają się w rurach łazienkowych, w lustrach, w króliczych norach, w kominach i dziurkach w nosie (Bator 2012: 36).

Pamięć o dziecięcej próbie wyrażenia, a zarazem oswojenia zła - trzeba je ,jakoś" nazwać, przekonywała starsza siostra bohaterkę, bo wszystko „jakoś się nazywa” - odsłania rzeczywistą bezradność języka w kształtowaniu obrazów okrucieństwa świata. Dziwaczne określenie „kotojady” oznacza złych ludzi i samą istotę zła, którym zarażają lub niszczą swoje ofiary.

Język bohaterów utworu, dotkniętych krzywdą lub pozostających w polu jej rażenia, obfituje w stylistyczno-semantyczne kontrasty, nieporadne neologizmy i kolokwializmy sąsiadujące z wulgaryzmami. Naznaczony trwałą dysharmonią kod, pełen paradoksalnych połączeń i nieoczekiwanych zderzeń znaczeniowych, odsłania swą niewspółmierność stylistyczną w stosunku do prezentowanego dramatu. Emocje okaleczone lub takie, które nie mogły się ukształtować i dojrzeć, przyczyniają się do utraty języka zdolnego nazwać, a zatem i rozpoznać destrukcyjny wymiar traumatycznych doświadczeń - a w konsekwencji być może nawet umożliwić proces ozdrowieńczy. Utrata języka utrudnia kolejne próby zapanowania nad sferą emocjonalną.

Psychika narratorki prezentowana w jej werbalnej reakcji na rzeczywistość ulega rozdwojeniu: trzeźwemu spojrzeniu na serię wypadków, prowadzących w konsekwencji do odkrycia niepojmowalnej krzywdy wyrządzanej uprowadzonym dzieciom, towarzyszy irracjonalny lęk przed „kotojadami” (nadal w ten sposób nazywanymi przez dorosłą kobietę) i ich przemożną siłą. Próba rozwiązania tajemnicy zniknięcia trójki wałbrzyskich dzieci staje się równocześnie próbą dojrzałego zmierzenia się 
z traumą własnego dzieciństwa. Zgodnie z radami osób postronnych oraz własnym rozeznaniem, Alicja „szuka niekochanych”, podąża tropem odrzuconych ${ }^{3}$, tym samym jednak jest zmuszona zmierzyć się z czasem, który nieustannie, w odruchu samoobrony, spycha w sferę nieświadomości.

Drugą z przyczyn niefortunnego włączania doświadczenia w pole jednostkowej egzystencji wskazanych przez Teresę Walas jest:

represyjne działanie systemu symbolicznego względem doświadczenia, powodujące jego usunięcie poza sferę wyrażania i reprezentacji lub przynajmniej bardzo wyraźne ograniczenie jej pola. Za pomocą tego mechanizmu kultura wyznacza - w sposób historycznie zmienny i różny na różnych swych obszarach - strefy doświadczenia wstydliwego, odtrąconego, swoistego ,abjectu”, i albo konsekwentnie pokrywa to milczeniem, albo przebiera w formy symbolizacji zastępczej, albo wreszcie zamyka w izolowanych rewirach (Walas 2012: 281).

Bohaterka Ciemno, prawie noc jest dojrzałą, wykształconą, samodzielną kobietą - mieszka sama i utrzymuje się z własnej pracy - sprawia wrażenie pozbawionej przesądów i uprzedzeń. Jednak już pierwsza noc spędzona w rodzinnym domu wywołuje w niej niezrozumiałe emocje. Wspomnienie ojca porzucającego córki dla mrzonki o poszukiwanym bez wytchnienia skarbie, ukrytym rzekomo w rozległych, niezbadanych tunelach pod Zamkiem Książ, przeplata się z obrazami z przeszłości, związanymi z najważniejszą w jej życiu osobą, siostrą Ewą. Oboje zmarli tragicznie - ojciec w wypadku, siostra śmiercią samobójczą - oboje też okazują się w ostatecznym rozrachunku uciekinierami ze świata, do którego nie potrafili się dopasować. Natomiast stary, zniszczony, poniemiecki dom przechowuje pamięć o przeszłości i aktywizuje jej najgłębsze pokłady.

Alicja w początkowej fazie swej podróży potrafiła jeszcze reagować na świat zewnętrzny tak, jak to robiła w ,zwyczajnym” życiu. Stwierdzała na przykład beznamiętnie:

${ }^{3}$ Znamienny jest tu przypadek sześcioletniego Patryka, z pewnością kochanego przez opiekującą się nim ubogą i zniedołężniałą babcię - zostaje nielegalnie oddany zamożnej niemieckiej rodzinie chcącej się nim zaopiekować. Nie trafia do piekła okrutnych twórców pornografii dziecięcej, w którym znalazły się pozostałe ofiary, dwie dziewczynki, jego równolatki - nie zmienia to jednak faktu, że i on - niezależnie od przyszłych losów - jest dzieckiem porzuconym przez matkę, wyłączonym ostatecznie z obszaru jej emocji, a nawet jej zainteresowania. 
Robiłam w tym roku reportaż o piętnastolatce, która zabiła swoje nienarodzone dziecko, wepchnęła je do plecaka, a potem poszła na dyskotekę. I o starszym mężczyźnie, który po śmierci dziewięćdziesięcioletniej matki zamurował ją pod kuchennym parapetem, by w kobiecym przebraniu odbierać jej rentę (Bator 2012: 53).

Jednak dom przepełniony odrzuconymi wspomnieniami i miasto przesycone negatywnymi emocjami zbiorowości egzystującej w permanentnej niezgodzie, stały się nieoczekiwanymi katalizatorami procesu samopoznania.

W pamięci bohaterki zaczynają wkrótce przewijać się wspomnienia o matce: groźne i niepokojące. Szczególnie często przywoływany jest jej obraz ze wzniesionym nad córką nożem. Pojawia się wspomnienie ciosu, po którym matka ostatecznie odeszła z życia kalekiej rodziny. Zbrodnicza Medea opuściła dom - w okolicznościach niejasnych dla kilkuletniej wówczas Alicji - z pozoru nie dokonawszy swego czynu. Zygmunt Kubiak w Mitologii Greków i Rzymian wskazywał, że antyczna Medea, okrutna dzieciobójczymi, była także ofiarą - to bogowie wyznaczyli przebieg jej biografii (Kubiak 1997: 488). Los Medei został przypieczętowany wyrokiem sił wyższych, natomiast jej portret jako wcielenia bezlitosnej, kobiecej żądzy mordu został wcześnie dookreślony w przestrzeni kultury europejskiej. W niektórych antycznych wariantach tej krwawej historii, Medea jeszcze pozostawała postacią niejednoznaczną: ,nie zabiła swoich dzieci, przeciwnie, chciała ocalić je, zostawiając chłopców jako błagalników u ołtarza Hery, pod możną opieką bogini. To Koryntianie ukamienowali ich (...). A przecież dzieci były niewinne, więc za karę ginęły odtąd korynckie dzieci, dopóki z nakazów wyroczni delfickiej nie ustanowiono dorocznych obrzędów przebłagalnych" (Kubiak 1997: 498). Z czasem natomiast utrwalił się jej wizerunek dzieciobójczyni niezasługującej na łaskę.

W powieści Joanny Bator matka godząca córkę nożem również zdaje się usprawiedliwiona. Jednak to nie siły wyższe determinowały jej okrutne postępowanie wobec własnego potomstwa. Opowieść naocznego świadka odsłania głęboko skrywaną tożsamość matki Ewy i Alicji: dziecka skrzywdzonego przez zbrodniarzy wojennych. Zbiorowy gwałt dokonany przez sowieckich żołdaków na dwunastoletniej dziewczynce na zawsze zniszczył

${ }^{4}$ Świadek ten jest także ofiarą - żołnierze ukarali chłopca broniącego przyjaciółki, zdzierając mu skórę z głowy. Oskalpowanie pozostawiło trwały, nieusuwalny ślad fizyczny, jednak nie doprowadziło do destrukcji sfery psychicznej. 
jej psychikę i zdolność odczuwania pozytywnych emocji. Unicestwił także możność odnalezienia słów, w których potrafiłaby opisać doświadczenie. Takis Theodoropoulos, tworząc swoją współczesną renarrację mitu Medei, wskazywał, że może być on odczytywany jako jeden z nacechowanych uniwersalnie wzorców kobiecego doświadczenia. Kolchidzka księżniczka samotnie zmagająca się z nieszczęściem, fatum, niechcianym i niewybranym przez siebie losem, przekształca się w „byt graniczny”:

Złożyła w ofierze Kreona, władcę Koryntu, jego córkę, nową żonę Jazona, a także własne dzieci (...) Zerwawszy wszystkie związki z przeszłością, porzucona, zdesperowana, pozbawiona przyszłości Medea ma dość siły, by przekroczyć granice swojego człowieczeństwa. Przekształca się w coś w rodzaju bytu granicznego, który porusza się po krawędzi, tam gdzie ani boska, ani ludzka sprawiedliwość nie może go dosięgnąć (Theodoropoulos 2009: 110).

Tym samym żądza czynienia zła, gotowość popełnienia najgorszych zbrodni jest gestem destrukcji - skierowanej przeciw okrucieństwu świata oraz autodestrukcji - niszczenia egzystencji ostatecznie skażonej złem. Podobnie można odczytywać historię matki, samotnie zmagającej się z traumą, która zmieniła nawet tożsamość, by odciąć się od przeżytej tragedii. Rosemarie przeobraziła się w Annę Lipiec, jednak przemiana okazała się pozorna i jedynie powierzchowna. Tragiczne w skutkach wyparcie traumatycznego doświadczenia - ukazywane w planie utworu jako nieuleczalne porażenie złem, czyli wniknięcie „kotojadów” do psychiki i przejęcie nad nią władzy - determinuje dalsze losy całej rodziny.

Medea współcześnie (historia Medei powtarzana dzisiaj) może pozostawać w sakralizowanej sferze tradycji, obciążonej pamięcią wcześniejszych realizacji, a jednak dążącej, podobnie jak większość z nich, do wydobycia z tkanki tekstu znaczeń uniwersalnych. Przyjęcie takiej perspektywy umożliwia zachowanie dystansu, skupienie się na kulturowym wymiarze figury Medei, thumaczy uznanie zamordowanych dzieci za ofiary konieczne, postrzeganie ich w sposób bezosobowy, a więc beznamiętny. Jednak w powieści Bator zło jednoznacznie zostaje przypisane do sfery profanum i do chtonicznie nacechowanych przestrzeni współczesnego „piekła na

${ }^{5}$ Autor podkreśla też, że w finale tragedii Eurypidesa dzieciobójczymi zostaje uniewinniona: „Udaje się do Aten, by poślubić króla Egeusza i dać mu dzieci, których dotąd nie mógł mieć" (Theodoropoulos 2009: 110). 
ziemi”. Natomiast narracja o dzieciobójczyni ukazywana z perspektywy krzywdzonego dziecka utrudnia, jeśli nie uniemożliwia, znalezienie usprawiedliwienia dla jej czynów.

Proces rekonstrukcji przeszłości prowadzi do swoistego przekierowania empatii, świadomie wpisywanej w narrację jako pożądana dyrektywa odbioru. Odnaleziony po latach list Ewy adresowany do młodszej siostry, uświadamia bohaterce, że rzeczywistą sprawczynią samobójczej śmierci nastolatki jest matka i jej niepojęte działania wobec starszej córki. List okazuje się skargą, którą trudno wyrazić odpowiednim językiem. W dodatku samo przywołanie, wyciągnięcie na światło dzienne przykrych wydarzeń, może okazać się traumą. W przesłaniu zza granicy śmierci znajduje się znamienne rozpoznanie, określające świadomość nastoletniej ofiary: „Wybacz, że muszę Ci to powiedzieć, a i tak nie będę w stanie wszystkiego, bo jak powiedzieć coś, na co nie ma słów?" (Bator 2012: 228). Niezborna opowieść musi jednak toczyć się dalej, by udokumentować w nieporadnych słowach rozmiar krzywdy: „Bałam się cały czas. Że przyjdzie naga, że ręka na moich ustach, że ręka przytrzymująca moją głowę. Moja głowa między jej nogami. Taka zdrada, czy wiesz, jak boli taka zdrada?" (Bator 2012: 229).

Wiedza o tragicznej przeszłości matki pozwala co prawda zrozumieć przyczyny jej postępowania i rozmiar zniszczeń, jakim podległa jej psychika, nie jest jednak w stanie zapobiec osądowi, któremu musi podlegać skala i ostatecznie destrukcyjny wymiar jej czynów. Opowieść kolejnego krzywdzonego dziecka (wciąż usiłującego zrzucić przynajmniej część winy za zło, które je spotykało na „kotojady”) uświadamia także przemożną siłę zła i jego przenoszone na następne pokolenia „długie trwanie”:

Mówiła, że jestem brudna i śmierdzę. Nalewała całą wannę gorącej wody i zanurzała mnie w niej z głową, przytrzymywała. Najbardziej interesowało ją, czy jestem czysta tam. Nie umiem użyć innych słów, a te niezdarne bolą strasznie. Może byłoby lepiej gdyby ten cały brud spłynął razem ze mną i z nią prosto do piekła. Dziecko płakało, prosiło: „mamo, mamo, już jestem czysta, mamo, proszę, nie”. Ale to nie pomagało. Lewatywa. Bolało, od środka rozrywał się brzuch. „Szpara śmierdzi grobem” mówiła z wykrzywiona twarzą (Bator 2012: 229).

Przyczyną popełnionego przez nastoletnią ofiarę samobójstwa okazała się więc nieuleczalna w istocie trauma, która uniemożliwiła podjęcie normalnego życia i prowadziła do aktów autodestrukcji, odczytywanych 
przez postronnych jako efekt choroby psychicznej - a na koniec do zaplanowanego z zimną krwią matkobójstwa ${ }^{6}$. Powodem desperackiego kroku była zapowiedź powrotu matki ze szpitala psychiatrycznego (została tam osadzona po nieudanym zamachu na młodszą córkę) i równoznaczna z nią groźba powtórzenia doświadczeń i podzielenia przez Alicję losu starszej siostry Ewy. Odejście Ewy było też specyficznym, nie do końca świadomym, aktem dzieciobójstwa - umierając była najprawdopodobniej w ciąży. Z jej perspektywy zabranie $\mathrm{z}$ sobą innego istnienia poza granicę śmierci, było jednak przede wszystkim jego uratowaniem przed grozą egzystencji.

Ten sam temat - dzieciobójstwa połączonego z samobójstwem - zyskał odmienny kształt, a tym samym posłużył innym celom w powieści Justyny Bargielskiej Małe lisy. W zakończeniu znużona jałową codziennością bohaterka, matka dwójki dzieci, postanawia popełnić samobójstwo. Życie jako ciągłe dostawanie tej samej lekcji, której gorzkim podsumowaniem było stwierdzenie: „wszystko, poza posiadaniem dzieci, okazało się gorsze niż się spodziewałam” (Bargielska 2013: 94), utraciło dla niej sens. Magda, jasno określając swoje pryncypia - „Nie potrafiłabym żyć bez moich dzieci, więc dlaczego miałabym w ogóle próbować bez nich nie żyć?” (Bargielska 2013: 96) - postanawia odejść ze świata razem z Klimkiem i Klarą ${ }^{7}$.

Czyn określony jako „samobójstwo rozszerzone” zostaje co prawda (inaczej niż w Ciemno, prawie noc) udaremniony, nie ma jednak pewności, czy nie dojdzie do kolejnej próby. Bargielska skupiła uwagę na wewnętrznych motywacjach, mogących doprowadzić do gestów ostatecznych, starała się wskazać na jednostkowy wymiar niepoddających się racjonalnemu osądowi decyzji. Codzienność okazuje się - i ta diagnoza jest wspólna dla Bator i dla Bargielskiej - wszędzie podobna: zagrożona śmiercią, rozpadem, niespełnieniem. Tym samym podjęcie próby ucieczki z dotkliwie ciążącej egzystencji może wymykać się jednoznacznej ocenie.

W cytowanym na początku artykule Teresa Walas wskazuje na jeszcze

${ }^{6} \mathrm{~W}$ przywołanym liście padają też słowa: „Dziecko nie wiedziało, gdzie się ono kończy, a gdzie zaczyna się ona". Można pokusić się o stwierdzenie, że takie wynaturzone zniszczenie autonomii dziecka było jedną z przyczyn późniejszych dramatycznych wypadków.

${ }^{7}$ Podobny przykład „samobójstwa rozszerzonego" stał się tematem filmu Plac Zbawiciela w reżyserii Joanny i Krzysztofa Krauze z 2006 roku. 
jeden wariant utrudnień (owej „niefortunności) w procesie rozpoznawania przez podmiot codziennych przeżyć jako możliwych do zrozumienia i zinterioryzowania:

W przypadku trzecim, najmniej oczywistym, możemy mówić o „uprzezroczystnieniu” doświadczenia lub nawet jego anihilacji. To sytuacja, gdy staje się niewidoczne w systemie rejestracji wytworzonym przez kulturę, a przez to w jakiejś mierze niewyczuwalne jako doświadczenie. Jest nieprzyswajalne nie dlatego, że symboliczny system kultury odrzuca je jako „niewyobrażalne”, „nie do pomyślenia”, „obrzydliwe”, lecz z tego względu, że ma ono w nim zbyt niską wartość egzystencjalną, zanika jako doświadczenie (Walas 2012: 282).

Tym samym także codzienne obcowanie ze złem, nieprawością, krzywdą słabszych, nieszczęściem odrzuconych i wykluczonych staje się pozbawionym refleksji trwaniem, niewymagającą reakcji egzystencją, a nawet wegetacją, nieprowadzącą ani do samopoznania, ani do prób zrozumienia świata. W takiej rzeczywistości ,kotojady” przestają się odróżniać od innych osób - albo to większość ludzi nabiera ich cech i przyzwala na zło w sobie, przestając je jako zło postrzegać i nazywać.

Obserwowany od dłuższego czasu rozpad więzi społecznych i rodzinnych wydaje się procesem przebiegającym z dostrzegalnym przyspieszeniem, w mediach coraz częściej pojawiają się wiadomości o kolejnych, niezliczonych już, aktach przemocy w rodzinach, śmiertelnych pobiciach, porzuceniach, zaniedbaniach prowadzących do tragedii. Dążenie do rozpowszechniania tego typu informacji wiąże się ze wzrastającym zapotrzebowaniem odbiorców oraz przemianami zachodzącymi w sferze obiegów informacyjnych - jednak ich podstawą są rozgrywające się realnie w przestrzeni społecznej zdarzenia.

Proliferacja najbardziej nawet okrutnych obrazów prowadzi, jak wiadomo, do ich inflacji. Diagnozowaniu podlega już fakt swoistego przesycenia przestrzeni medialnej informacjami o takich nieszczęściach, w tym o zabójstwach dzieci dokonywanych przez rodziców, najczęściej przez matki. Zjawisko nadreprezentacji kolejnych aktów dzieciobójstwa w sferze publicznych obiegów komunikacyjnych prowadzi do swoistego znieczulenia - powtarzane w stylistyce medialnych doniesień, jednodniowych sensacji, internetowych „ciekawostek”, zlewają się z innymi przekazami w szum informacyjny niepodlegający ani etycznemu namysłowi, ani nawet właściwemu rozpoznaniu. Jednym z pierwszych twórców stawiających 
taką diagnozę był Tadeusz Różewicz. Poeta wcześnie zaczął ukazywać efekt przenoszenia „wydarzeń medialnych” z przestrzeni publicznej w przestrzeń prywatną - najbardziej znanym przykładem demaskowania skutków takich działań stał się poemat Walentynki z tomu zawsze fragment, wydanego w 1996 roku. W pierwszej części poematu w bełkot „pani redaktorki radia bzdet", namawiającej do świętowania dnia zakochanych została wpleciona wiadomość:

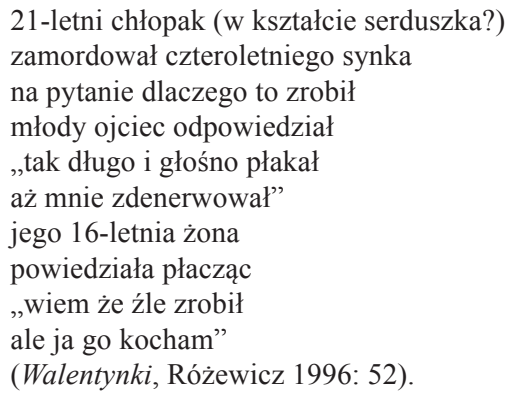

Różewicz pokazał, jak z jednej strony tragiczna historia bestialskiego zamordowania dziecka splata się z bełkotliwą promocją święta zakochanych i tym samym zostaje unieważniona, zdegradowana do rangi historyjek, których wiele - z drugiej strony odsłonił mechanizm, który sprawia, że młodociani mordercy bez poczucia winy stają się aktorami ohydnego spektaklu, powtarzającymi wcześniej zasłyszane (może na antenie tego samego radia) kwestie.

Medialne oswojenie ma destrukcyjne skutki, uzwyczajnienie zbrodni przestaje zaświadczać o rzeczywistych, jednostkowych tragediach. Mało kto jest w stanie przeciwstawić się rosnącemu zobojętnieniu na krzywdę wyrządzaną słabszym, zależnym, bezbronnym. Wydaje się, że jedną z przyczyn jest zanik języka, zdolnego wyrazić rzeczywisty wymiar tragedii, wypowiedzieć prawdziwie poruszający protest, rozbić rosnący mur zbiorowej obojętności. Różewicz w swojej późnej twórczości demaskuje skalę przyspieszenia procesu rozpadu więzi zbiorowych i utraty zdolności pojmowania sensów wyrażanych w formie bardziej skomplikowanej. Tworząc ironiczne odbicia medialnych i wirtualnych bełkotów, szumów, wynaturzeń języka, odsłania wynaturzenia zbiorowego życia. 
Podobną diagnozę stawia w swym utworze Joanna Bator. Trzy jego rozdziały, numerowane kolejno Bluzgi, poświęcone zostały próbie odtworzenia specyfiki wirtualnych dyskusji prowadzonych - w tym przypadku - przez członków lokalnej społeczności, a dotykających aktualnie rozgrywających się w powieściowym Wałbrzychu, wciąż niewyjaśnionych, spraw. „Rozmówcy”, ukrywający się za internetowymi nickami, w przepełnionych rozmaitymi błędami wypowiedziach, bezkarnie dają upust swym uczuciom: nienawiści, wyrosłej z uprzedzeń, ksenofobii, zawiści i głupoty. Zdarzają się, co prawda, wieści z pozoru nacechowane pozytywnie: - „aż się serce raduje, że jednak Polacy potrafią się łączyć wspólnie ze sobą w nieszczęściu. Szczęście w nieszczęściu, że w tym kraju jest tylu ludzi pozytywnie zakręconych" (Bator 2012: 340-341) - zazwyczaj jednak dzieje się tak, gdy autor ma dodatkowy cel (na przykład reklamowanie prowadzonego przez siebie bloga dotyczącego jasnowidzenia i innych „spraw nadprzyrodzonych”). Z reguły teksty funkcjonujące w wirtualnej przestrzeni przypominają ten, sygnowany przez „ProfessorHab.”:

Kastrować... owszem ale HORDĘ dziką o nazwie UE. To nie jest wyzwolenie ale NIEWOLA popędów, które rosną wykładniczo i prowadzą do zboczeń i napadów... Wprost zalewa nas przez to pornografia i żyjemy w nieustannym ZAGROŻENIU, mam nadzieję, że takich nieopogodzonych z dobrowolnym zezwierzęceniem własnej osoby bliźniego jest więcej (Bator 2012: 341).

Bełkotliwe wpisy, wszczynane niepotrzebnie dyskusje, rzucane bez zastanowienia obelgi demaskują przede wszystkim wypowiadających się na internetowych forach ludzi. Zapewnione im w wirtualnej przestrzeni poczucie anonimowości uwalnia od przymusu zachowywania jakichkolwiek reguł - nie służy budowaniu samoświadomości czy odpowiedzialności za własne czyny, także za dookreślone wyborem języka istnienie w świecie.

Podsumowaniem rozważań Teresy Walas o skutkach „niefortunności” w procesie interioryzowania doświadczeń jest wskazanie różnicy:

O ile w pierwszym z wyróżnionych wcześniej przypadków możemy mówić o rzeczywistym przyroście form wysłowienia lub o zjawisku niewyrażalności, które powstrzymuje komunikowalność doświadczenia, o tyle ten ostatni opisać by raczej należało nie tyle nawet jako „oniemienie”, ile jako ontologiczną zapaść, wytrącenie z bytowej pewności ze względu na brak substancji komunikacyjnej (Walas 2012: 282). 
Doświadczenie zwrotnie wytrącając swoją „namacalność”, stawia opór uobecnieniu w jednostkowej samowiedzy. Chociaż przepływa przez świadomość, jest słabo przez nią pochwytne, umyka pamięci, a tym samym pozostaje poza horyzontem kultury.

Takie „doświadczenie braku doświadczenia” ma status mglistych uogólnień, prowadzących z reguły do nieakceptacji samej egzystencji. Bohaterowie Ciemno, prawie noc nie potrafią odnaleźć sensu własnego istnienia, ale także nie znajdują sposobów nazwania przyczyn życiowej klęski. Nie umieją odnaleźć drogi prowadzącej do zrozumienia, a w konsekwencji wyrażenia własnych doświadczeń. Zdolnością pojmowania siebie i otaczającej rzeczywistości zostało obdarzonych, obok głównej bohaterki, niewielu. Jest to umiejętność dostrzegania zła w świecie i umiejętność empatycznego współodczuwania z krzywdzonymi - a zatem bolesnego otwarcia na cierpienie. Tym samym Bator stawia pesymistyczną diagnozę współczesności, którą wspomaga gest wyrażanej wprost odmowy akceptowania porządku społecznego, zbudowanego na przemocy i obojętności wobec najrozmaitszych przejawów wszechobecnego zła.

\section{Literatura}

Bargielska J., 2013, Mate lisy, Warszawa.

Bator J., 2012, Ciemno, prawie noc, Warszawa.

Kubiak Z., 1997, Mitologia Greków i Rzymian, Warszawa.

Leavitt J., 2012, Znaczenie i czucie w antropologii emocji, przeł. A. Kościańska, M. Petryk, w: Emocje w kulturze, red. M. Rajtar, J. Straczuk, Warszawa, s. 59-100.

Nycz R., 2012, Od teorii nowoczesnej do poetyki doświadczenia, w: Kulturowa teoria literatury 2, red. T. Walas, Kraków, s. 31-62.

Różewicz T., 1996, zawsze fragment, Wrocław.

Szpakowska M., 2008, Dzień Dziecka, w: Obyczaje polskie. Wiek XX w obrazach, red. M. Szpakowska, Warszawa, s. 54-65.

Theodoropoulos T. 2009, Podbój gościnnego morza, w: Odessa transfer. Reportaże znad Morza Czarnego, red. K. Raabe, przeł. P. Kordos, Wołowiec, s. 91-112.

Walas T., 2012, Literatura (kultura) jako selekcja i projektowanie doświadczenia, w: Kulturowa teoria literatury 2, red. T. Walas, Kraków, s. 273-310. 